\title{
1. Introduction: national regulatory autonomy and the Trans-Pacific Partnership Agreement
}

\section{Tania Voon}

As the Doha Round of multilateral trade negotiations within the World Trade Organization (WTO) continues to flounder, all eyes have turned to a series of plurilateral trade agreements being negotiated around the world, with the Trans-Pacific Partnership Agreement (TPP) at the centre. The core group of countries negotiating this agreement has expanded well beyond the initial members of the Trans-Pacific Strategic Economic Partnership Agreement ('P4'): New Zealand, ${ }^{1}$ Singapore, ${ }^{2}$ Brunei Darussalam $^{3}$ and Chile. ${ }^{4}$ Negotiations with the additional TPP partners of Australia, Malaysia, Peru, the United States and Vietnam began in Melbourne in 2010,5 with Canada and Mexico joining discussions in $2012^{6}$ and Japan most recently joining in $2013,{ }^{7}$ bringing the number of

1 Signed 18 July 2005 (provisionally entered into force 1 May 2006; officially entered into force 28 May 2006).

2 Ibid.

3 Signed 2 August 2005 (entered into force 12 July 2006).

4 Signed 18 July 2005 (entered into force 8 November 2006).

5 See, e.g., Update on the first round of Trans-Pacific Partnership (TPP) negotiations - a strong start, Australian Government, Department of Foreign Affairs and Trade <http://www.dfat.gov.au/fta/tpp/100326-tpp-stakeholderupdate-1.html>. See also, e.g., Meredith Kolsky Lewis, 'Expanding the P-4 Trade Agreement into a Broader Trans-Pacific Partnership: Implications, Risks and Opportunities' (2009) 4 Asian Journal of WTO and International Health Law and Policy 401.

6 See, e.g., Office of the United States Trade Representative, 'Trans-Pacific Partnership Leadership Statement' (Press Release, 9 September 2012) <http:// www.ustr.gov/about-us/press-office/press-releases/2012/september/tpp-leader ship-statement>; International Centre for Trade and Sustainable Development, 'Mexico, Canada Receive Invite to Trans-Pacific Trade Talks' (20 June 2012) 16(24) Bridges Weekly Trade News Digest (online). 
negotiating countries to 12 . At the time of writing in May 2013, the 17th round of negotiations is taking place in Peru. ${ }^{8}$

The global significance of the agreement is reflected not only in the already burgeoning literature on the subject, ${ }^{9}$ but more importantly in its potential economic benefits. The current negotiating countries in the TPP in 2012 had a collective GDP of more than US $\$ 27,500$ billion and a population of more than 790 million. ${ }^{10}$ Existing trade between TPP partners is extensive, with the United States a dominant partner. ${ }^{11}$ According to one study, adding Japan to the agreement (as is under way at the time of writing) will extend the global benefits of an agreement from $\$ 75$ billion to $\$ 223$ billion per year, and adding Korea (as may happen in the future) would further increase benefits to $\$ 295$ billion per year. ${ }^{12}$

The potential economic scope of the agreement means that, at a broader strategic level, the TPP could realistically provide a 'pathway'

7 See, e.g., Office of the United States Trade Representative, 'Joint Statement of TPP Ministers: Trans-Pacific Partnership Ministers Chart Path Forward on Key Issues and Confirm Next Steps on Japan's Entry' (Press Release, 20 April 2013) <http://www.ustr.gov/about-us/press-office/press-releases/2013/april/jointstatement-tpp-ministers >; International Centre for Trade and Sustainable Development, 'Japan Gets TPP Invite, as APEC Calls for Faster WTO Talks' (25 April 2013) 17(14) Bridges Weekly Trade News Digest (online).

8 See, e.g., Trans-Pacific Partnership (TPP): 17th Round of TPP Negotiations Set for Lima, Peru - May 15-24, 2013, Office of the United States Trade Representative $<$ http://www.ustr.gov/tpp $>$.

9 See, e.g., C.L. Lim, Deborah Elms and Patrick Low (eds), The TransPacific Partnership: A Quest for a Twenty-first Century Trade Agreement (Cambridge University Press, 2012); Jane Kelsey (ed.), No Ordinary Deal: Unmasking the Trans-Pacific Partnership Free Trade Agreement (Allen \& Unwin, 2010); Jeffrey Schott, Barbara Kotschwar and Julia Muir, Understanding the Trans-Pacific Partnership (Peterson Institute for International Economics, 2013).

10 Trans-Pacific Partnership Agreement negotiations, Australian Government, Department of Foreign Affairs and Trade <http://www.dfat.gov.au/fta/tpp/>. See also Brock Williams, 'Trans-Pacific Partnership (TPP) Countries: Comparative Trade and Economic Analysis' (CRS Report for Congress R42344, Congressional Research Service, 29 January 2013) 3.

11 Williams, above n 10, 5, 20-21.

12 Peter Petri, Michael Plummer and Fan Zhai, Adding Japan and Korea to the TPP (7 March 2013) Asia-Pacific Trade <http://asiapacifictrade.org/wpcontent/uploads/2013/03/Adding-Japan-and-Korea-to-TPP.docx >. 
towards further economic integration ${ }^{13}$ among the current and additional parties, particularly through the possibility of a 'Free Trade Area of the Asia-Pacific' as envisaged by the Asia-Pacific Economic Cooperation (APEC) forum ${ }^{14}$ and as discussed further in Chapter 3 of this volume. The TPP negotiating parties already have a complex web of preferential trade agreements (PTAs) between them. ${ }^{15}$ At the same time, other major plurilateral trade and investment negotiations are taking place in various contexts.

The Regional Comprehensive Economic Partnership (RCEP) negotiations commenced in late 2012 among 16 countries (that is, the 10-member Association of Southeast Asian Nations (ASEAN) plus the six countries with existing PTAs with ASEAN). ${ }^{16}$ The goal of the RCEP negotiations is 'to achieve a modern, comprehensive, high-quality and mutually beneficial economic partnership agreement among the ASEAN Member States and ASEAN's FTA Partners', covering a broad range of areas including trade in goods and services, investment, technical cooperation, intellectual property, competition and dispute settlement. ${ }^{17}$

In February 2013, President Obama announced the intention of launching negotiations between the United States and the European Union towards a Transatlantic Trade and Investment Partnership (TTIP), 'envisioned as an ambitious, high-standard trade and investment agreement' between parties that already account for 'one third of total goods and

13 See generally, e.g., Meredith Kolsky Lewis, 'Achieving a Free Trade Area of the Asia-Pacific: does the TPP present the most attractive path?' in C.L. Lim, Deborah Elms and Patrick Low (eds), The Trans-Pacific Partnership: A Quest for a Twenty-first Century Trade Agreement (Cambridge University Press, 2012) 223; Peter Petri, Michael Plummer and Fan Zhai, 'The Trans-Pacific Partnership and Asia-Pacific Integration: A Quantitative Assessment' (East-West Center Working Papers: Economic Series No 119, East-West Center, 24 October 2011).

14 See, e.g., APEC Secretariat, 'Regional initiatives boost pursuit of APECwide free trade area' (News Release, 22 November 2012).

15 Ian Fergusson et al., 'The Trans-Pacific Partnership Negotiations and Issues for Congress' (CRS Report for Congress No R42694, Congressional Research Service, 15 April 2013) 6.

16 The ASEAN members are Brunei Darussalam, Cambodia, Indonesia, Laos, Malaysia, Myanmar, Philippines, Singapore, Thailand and Vietnam. The additional countries are Australia, China, India, Japan, the Republic of Korea and New Zealand.

17 Guiding Principles and Objectives for Negotiating the Regional Comprehensive Economic Partnership (2012) ASEAN <http://www.asean.org/images/2012/ documents/Guiding\%20Principles\%20and\%200bjectives $\% 20$ for $\% 20$ Negotiating\% 20the\%20Regional\%20Comprehensive\%20Economic\%20 Partnership.pdf>. 
services trade and nearly half of global economic output'. ${ }^{18}$ Already some stumbling blocks have started appearing in the initial talks, such as European concerns about the treatment of audiovisual products in the agreement. ${ }^{19}$

Negotiations are also continuing among more than 20 WTO Members including the European Union (representing 27 countries) towards an extensive plurilateral agreement on services, variously termed the 'International Services Agreement'20 and the 'Trade in Services Agreement'. ${ }^{21}$ As discussed further in Chapter 7 of this volume, these negotiations similarly aim for an ambitious, high-quality agreement in the specific context of trade in services.

The simultaneous negotiation of a range of novel, broad-reaching plurilateral agreements affecting matters including trade in goods, trade in services, intellectual property and investment raises a number of questions and potential problems. In particular, what impact will these different negotiations have on the TPP? To what extent will success, failure, trade-offs or conclusions reached in one forum affect others? Debate exists, for example, as to the compatibility of the TPP and the RCEP, and whether these are properly regarded as alternative or concurrent tracks towards the goal of deeper integration in the Asia-Pacific. ${ }^{22}$ These numerous ongoing negotiations, not to mention moves towards additional bilateral treaties, may lend an urgency to the TPP discussions, providing an additional impetus to reach agreement in the TPP given the competing demands and opportunities.

18 Fact Sheet: United States to Negotiate Transatlantic Trade and Investment Partnership with the European Union (13 February 2013) Office of the United States Trade Representative <http://www.ustr.gov/about-us/press-office/factsheets/2013/february/US-EU-TTIP>.

19 See, e.g., 'EU Parliament Resolution Backs Audiovisual Exclusion in U.S.-EU Talks' (3 May 2013) 31(18) Inside US Trade (online). See also 'A transatlantic tipping-point', The Economist (online), 27 April $2013<\mathrm{http}: / / \mathrm{www}$. economist.com/news/united-states/21576704-historic-trade-pact-between-americaand-europe-needs-saving-transatlantic $>$.

20 Office of the United States Trade Representative, 'Interagency Trade Policy Group Holds Public Hearing on Negotiating Objectives for International Services Agreement Negotiations' (Press Release, 12 March 2013) <http://www. ustr.gov/about-us/press-office/press-releases/2013/march/tpsc-services-hearing >.

21 Trade in Services Agreement (TISA), Australian Government, Department of Foreign Affairs and Trade <http://www.dfat.gov.au/trade/negotiations/services/ trade-in-services-agreement.html $>$.

22 'TPP Officials See RCEP as Complementary, but U.S. Businesses Worried' (23 November 2012) 30(46) Inside US Trade (online). 
All of these negotiations, and the steps being taken towards the TPP in particular, have given rise to an overarching concern about the impact of additional trade and investment agreements on national regulatory autonomy. Questions about the extent to which international trade and investment agreements constrain state sovereignty are not new. Even bilateral agreements between only two parties can create major problems for future governments in implementing their preferred policies, as was feared and arguably eventuated in the case of the Australia-United States Free Trade Agreement (AUSFTA), ${ }^{23}$ with Australia losing out. ${ }^{24}$ Concerns about the impact of international trade and investment law on public policy are frequently exacerbated by the processes by which international agreements are reached, which in many countries are non-transparent and impenetrable by external stakeholders. ${ }^{25}$

In the case of the TPP, an additional element of conspiracy was added by the negotiating partners' pact of secrecy. As explained by the Office of the United States Trade Representative:

Major trade and investment negotiations address a broad range of often complex and commercially sensitive sectors and issues and often take many months or even years to conclude. In order to reach agreements that each participating government can fully embrace, negotiators need to communicate with each other with a high degree of candor, creativity, and mutual trust. ... [W] hen the TPP negotiations got underway in 2009, the United States and its TPP negotiating partners entered into a confidentiality arrangement reflecting the customary understanding between countries engaged in trade negotiations that the negotiations should be carried out in private. ${ }^{26}$

23 Signed 18 May 2004, [2005] ATS 1 (entered into force 1 January 2005).

24 See, e.g., Andrew Mitchell and Tania Voon, 'Australia - United States Free Trade Agreement' in Simon Lester and Bryan Mercurio (eds), Bilateral and Regional Trade Agreements: Case Studies (Cambridge University Press, 2009) 6, 42-43. See also Linda Weiss, Elizabeth Thurbon and John Mathews (eds), How to Kill a Country: Australia's Devastating Trade Deal with the United States (Allen \& Unwin, 2004).

25 See, in the context of Australia, the WTO and the AUSFTA, Hilary Charlesworth et al., No Country Is an Island: Australia and International Law (UNSW Press, 2006) 112-140.

26 FACT SHEET: Transparency and the Trans-Pacific Partnership (June 2012) Office of the United States Trade Representative <http://www.ustr.gov/ about-us/press-office/fact-sheets/2012/june/transparency-and-the-tpp>. 
The broad contents and framework of the confidentiality agreement between the TPP partners were released in 2011.27 The partners agree to hold negotiating documents 'in confidence for four years after entry into force of the Trans Pacific Partnership Agreement, or if no agreement enters into force, for four years after the last round of negotiations'. ${ }^{28}$

The continued refusal of parties to release draft texts or proposals through official channels has understandably increased fears among the various national communities involved that an agreement would be reached without fully taking account of their particular interests. Uncertainty and pessimism have not been alleviated by the occasional leaking of draft texts and proposals, without the necessary context surrounding the origins of the texts and proposals or their reception in negotiations. Opportunities to make submissions to negotiating governments in writing and in periodic stakeholder meetings have offered little comfort in the absence of any assurance that negotiators are taking such views into account and without the possibility of meaningful responses from negotiators.

Against that background, one purpose of this volume is to provide timely input into the negotiations and qualitative principles for assessing a final TPP agreement. Rather than focusing on a close interrogation of the specific wording of leaked texts, which may or may not represent conclusions reached by the TPP partners in negotiations, the authors reflect on broader, enduring questions raised by the TPP and fundamental implications of the TPP for the future of international trade, investment, law and public policy. Most chapters in this volume were finalised in March or April 2013, ${ }^{29}$ and negotiations have progressed since then. The volume nevertheless presents a broad and deep analysis of many of the primary legal and policy issues arising through the TPP negotiations, which will continue to be of concern upon the conclusion of the negotiations. In particular, each chapter explores different dimensions of the relationship between the TPP and national regulatory autonomy, taking account of legal, economic, political and sectoral perspectives.

27 Mark Sinclair, TPP Talk: Content of confidentiality letters (29 November 2011) New Zealand Ministry of Foreign Affairs \& Trade <http://mfat.govt.nz/ Trade-and-Economic-Relations/2-Trade-Relationships-and-Agreements/TransPacific/1-TPP-Talk/0-TPP-talk-29-Nov-2011.php>.

28 Ibid., linking to model letter: <http://mfat.govt.nz/downloads/tradeagreement/transpacific/TPP\%20letter.pdf $>$.

29 Chapter 6 was finalised in February 2013, and Chapters 1, 5 and 7 in May 2013. 
In Chapter 2, Won-Mog Choi explains the TPP within the broader context of the proliferation of PTAs and the implications of the agreement for the harmonisation of rules of origin, which are used to identify the origin of a given product and hence the conditions under which preferential treatment may be granted under a PTA. Highlighting the different models for rules of origin adopted across the world, Choi emphasises the potential distortions that may arise from the use of particular rules of origin, as well as the significant business costs arising from divergent rules of origin. While multilateral harmonisation may not yet be possible, the TPP offers an opportunity for significantly increasing the consistency of rules of origin globally by harmonising rules on intra-TPP trade, thereby multiplying the benefits of unilateral, regional and multilateral trade liberalisation.

In Chapter 3, Meredith Kolsky Lewis tackles an equally significant, cross-cutting issue, namely the relationship between the TPP and development. The TPP's importance for development lies in the unusual diversity of its parties and breadth of its coverage. Comparing PTAs with the WTO, including the WTO's concept of 'special and differential treatment' for developing countries, Lewis identifies differences in bargaining structures that may weaken the negotiating strength of developing countries in bilateral and plurilateral trade negotiations and environments. However, she explains that the TPP presents novel circumstances, as 'the first plurilateral FTA to be negotiated amongst several developed and several developing countries from non-congruent parts of the world', and because the negotiators have specifically identified development as one of the cross-cutting issues to be addressed. Developing countries may derive significant benefits from the agreement simply by virtue of its potential for deeper integration and market access, but other TPP areas are more problematic, including heightened intellectual property protections, the introduction of binding commitments on labour and the environment, and strict rules of origin. The outcomes on these issues may set a precedent for other PTAs and the WTO itself, increasing the significance of the TPP from a development perspective.

In Chapter 4, Kimberlee Weatherall examines in greater detail the implications of the TPP for intellectual property. Like other aspects of the TPP, intellectual property negotiations in the TPP present new challenges - such as the broad regional trade aspirations underlying the TPP alongside old concerns - such as the ambitions of the United States for higher levels of intellectual property protection. Weatherall clarifies how these different factors may influence the outcome of the intellectual property negotiations. For example, 'the RCEP ... represents a possible future competitor for a regional framework: one which is likely to 
contain provisions on IP more palatable to regional powers than anything the US might push in the TPP'. Thus, ongoing negotiations towards the RCEP may dampen efforts towards stringent intellectual property provisions in the TPP. As Weatherall demonstrates, broader public unease about increasing intellectual property protections through international agreements may have a similar tendency to the extent that such sentiments influence the TPP negotiations. Intellectual property thus provides a clear case study of the potential for actual and perceived conflict between public policy and the TPP.

Chapter 5 presents a more concrete case study of that same issue, with Matthew Rimmer addressing the intersection between tobacco control and the TPP, with specific reference to Australia's law mandating the standardised packaging of tobacco products. Rimmer highlights procedural problems with the TPP negotiations in the context of tobacco, including the influence of the tobacco industry on proceedings. Having regard to the legal disputes concerning so-called 'plain' packaging within Australia and internationally, Rimmer also draws connections between the TPP, health and intellectual property such as trade marks on tobacco packages. Rimmer considers related developments in New Zealand and the United States, focusing in particular on the United States' proposal regarding tobacco in the TPP.

In Chapter 6, Deborah Elms discusses the pervasive problem of agriculture in the TPP, against the background of the treatment of agriculture in the WTO and existing PTAs. As always, agriculture raises highly sensitive issues and sectors, yet Elms notes that some of the difficulties of agricultural negotiations are alleviated in the TPP, for example due to the existing PTAs between the TPP partners and the absence of competition between them in relation to some agricultural products. But sugar and dairy remain sticking points in the agricultural negotiations, along with how to address tariff rate quotas and rules of origin in the TPP. Elms concludes that success in the agricultural talks is imperative in reaching the ambitions of the TPP partners for a highquality agreement.

Danny Kotlowitz and I take telecommunications as a case study of services in the TPP, in Chapter 7. Placing the TPP negotiations within the context of other developments concerning the international regulation of telecommunications services, we reflect on the plurilateral services negotiations already mentioned as well as the revised International Telecommunications Regulations adopted by some Member States of the International Telecommunication Union. We then emphasise the opportunity presented by the TPP and similarly ambitious trade negotiations to create a new breed of telecommunications chapter in PTAs, breaking with 
outdated approaches to classification of telecommunications services and related obligations. Finally, we offer a brief critique of the suggestion that the TPP might be used to address international mobile roaming charges through plurilaterally agreed regulations.

The next two chapters deal with different forms of dispute settlement that may emerge through the TPP: first in Chapter 8, where Andrew Mitchell and James Munro explore the implications of the TPP for state-state dispute settlement, and then in Chapter 9, where Leon Trakman outlines the options for investor-state dispute settlement in the TPP. Mitchell and Munro consider how a new dispute settlement mechanism in the TPP for resolving TPP-related disputes among TPP partners would relate to existing dispute settlement fora under PTAs and the WTO, taking into account the rules regarding treaty interpretation and conflicts of norms or jurisdiction under public international law. Trakman addresses the rather more controversial question of whether and in what terms investors might be permitted to bring claims against host governments under the TPP. For Australia, as he discusses in detail, the issue appeared closed, at least for the government led by Julia Gillard, which had already indicated its general opposition to investor-state dispute settlement in the TPP and more generally. Trakman goes on to analyse the nuanced pros and cons of the position taken by Australia, including the relevance of the investment claim already brought against Australia in connection with plain tobacco packaging, as discussed in Chapter 5.

In Chapter 10, Joshua Meltzer returns to a core site of potential conflict between public policy, trade and investment, reflecting on the TPP's significance for the environment and climate change. Acknowledging the power of the United States in the TPP negotiations, he first provides a detailed examination of that country's approach to the environment in its existing PTAs, as a basis for determining the likely preferences and interests of the United States in the TPP context. Meltzer then describes two specific environmental problems that may need to be addressed in the TPP: trade in illegally harvested timber, and fisheries subsidies. Meltzer demonstrates that the environmental implications of the TPP are not limited to the environment chapter or specific references to the environment in particular provisions. Trade in environmental goods, for example, will be significantly affected by the potential tariff cuts and reduction in non-tariff barriers to be offered in the TPP. The chapter concludes by highlighting the potential positive impact of the TPP on the environment.

Finally, in Chapter 11, Rodrigo Polanco addresses the stated goal of achieving 'regulatory coherence' through the TPP negotiations, including 
through a dedicated chapter of the agreement designed to enhance transparency and coherence of regulations both within and between TPP partners. Polanco considers approaches to the concept of regulatory coherence adopted in other institutions such as the Organisation for Economic Co-operation and Development, pondering the utility of regulatory coherence in resolving a central question of this book: 'How can we secure the benefits of trade liberalisation without infringing the freedom of governments to pursue legitimate regulatory objectives?' Polanco ends on a cautionary note about the choice of instruments open to TPP negotiators in striving for regulatory coherence.

Together, the authors in this volume tackle the question posed by Polanco in various ways, recognising both the importance of the TPP in securing cross-global welfare benefits through an ambitious, marketopening deal, and the real potential for the TPP to disconnect sovereign governments from their policy goals and people. On the one hand, for example, deep and broad integration through the TPP and successor agreements - including in agriculture - may proffer lasting benefits for developed and developing countries alike. Harmonisation of rules of origin through the TPP and beyond similarly has the potential to greatly facilitate trade for the benefit of countries around the world. The framework for the negotiations and the countries involved mean that the parties have the chance to try new techniques in relation to a whole range of sectors including, for example, telecommunications. On the other hand, the potential for egregious errors to be made in areas such as health, the environment and intellectual property is high, with correspondingly high risks to the regulatory autonomy of TPP parties. These risks may be somewhat reduced by the parties taking a balanced approach to provisions on dispute settlement and regulatory coherence, and could be further mitigated by increasing the level of transparency in the course of negotiations. But, in the end, the TPP will be judged as a whole, and the world must wait to see with hindsight whether the negotiators have got it right. 